\title{
Važni koraci na ekumenskom putu u Katoličkoj Crkvi s kratkim osvrtom na katoličko-luteranski dijalog
}

\author{
IVAN MACUT* \\ UDK: 27-265-274.5 • Pregledni članak \\ Primljeno: 19. travnja 2017. • Prihvaćeno: 4. rujna 2017.
}

${ }^{*}$ Dr. sc. Ivan Macut, Katolički bogoslovni fakultet Sveučililšta u Splitu, Zrinskofrankopanska 19, 21000 Split, Hrvatska, ivanmacut@libero.it

Sažetak: U ovom se članku bavimo prikazom glavnih ekumenskih koraka koji su učinjeni u Katoličkoj Crkvi u odnosu na ekumenizam s posebnim naglaskom na katolicko-luteranski dijalog. Uz uvod i zaključak, clanak je podijeljen na četiri kraća poglavlja. U prvom poglavlju pod naslovom $\gg$ Molitvena osmina za jedinstvo kršćana u ukratko smo prikazali nastanak $i$ istaknuli važnost ove molitvene osmine. Naime, ona je često puta jedina ekumenska aktivnost tijekom cijele godine u mnogim župnim zajednicama. Drugo poglavlje govori o Drugom vatikanskom saboru i o ekumenskom otvaranju Katoličke Crkve kroz nekoliko različitih naglasaka: »Usmjerenost na ekumenizam《, »Tajništvo za sjedinjenje kršćana «, $\gg$ Prisutnost nekatoličkih promatrača na Saboru «, $\gg$ Novi pristup ekumenizmu - 'Unitatis redintegratio' «, »Subsistit in «, $\gg$ Hierarchia veritatum $\ll$. Tré́e poglavlje govori o uključivanju Katoličke Crkve u pokret »Vjera i ustrojstvo « dok se u četvrtom poglavlju govori o $\gg$ Zajedničkoj izjavi o opravdanju $<$ iz 1999. godine te o dokumentu iz 2013. godine pod naslovom $\gg$ Od sukoba do zajedništva«. Zaključno možemo reći kako stav Katoličke Crkve u 20. stoljeću prema ekumenizmu treba podijeliti na dva dijela: prije i nakon Drugog vatikanskog sabora. 500-ta obljetnica od početka Reformacije prigoda je da se još zdušnije nastavi ekumenski dijalog izmedu luterana $i$ katolika te da učinimo i posljednje korake prema vidljivom jedinstvu.

Ključne riječi: Molitvena osmina za jedinstvo kršćana, Drugi vatikanski sabor, luterani, Subsistit in, Od sukoba do zajedništva. 


\section{Uvod}

Već više od 100 godina u svijetu djeluje ekumenski pokret. Ova je činjenica razlog da se jedni razočarano upitaju ima li ekumenizam uopće više smisla jer već tako dugo nije postignut cilj ekumenskih nastojanja, a to je vidljivo jedinstvo, dok se drugi pak raduju činjenici da kršćani već tako dugo međusobno razgovaraju, približavaju se jedni drugima te ćemo na koncu doći i do ostvarenja toliko željenog vidljivog jedinstva Crkava i crkvenih zajednica. U svim kršćanskim zajednicama, pa tako i u Katoličkoj Crkvi, nailazimo na zagovornike obaju ovih pogleda koji se mogu opravdati različitim, više ili manje uvjerljivim, razlozima.

Osobno smo skloni u ekumenizmu vidjeti pozitivnu stvarnost koja unatoč svim svojim stvarnim problemima ipak kršćane približava jedne drugima te im otvara do prije samo 100 godina nezamislive mogućnosti i perspektive. Osim toga, biti zagovornik i vjerni promicatelj ekumenizma znači i pozitivno odgovoriti na Kristov poziv da svi kršćani budu jedno, a nitko tko sebe smatra istinskim Kristovim učenikom nema pravo oglušiti se na ovu Kristovu molitvu. Imajući na umu da je ekumenizam od Boga željena stvarnost, ne možemo se oglušiti na njegov poziv niti se možemo odnositi prema njemu ravnodušno. Kršćanin koji prihvaća ekumenizam kao izraz Božje volje ne može izgovarati ili pak zastupati mišljenje da $\gg$ od ekumenizma nema ništa korisnog ${ }_{\ll,} \gg$ da je ekumenizam gubljenje vremena «, »da je ekumenizam vođenje ispraznih i besplodnih rasprava «i sl. Iako će konačno vidljivo jedinstvo, kako je to već ranije rekao papa emeritus Benedikt XVI., na koncu biti Božji dar kršćanima i svijetu, ipak i mi imamo svoj dio zadatka koji trebamo ispuniti te se ono bez našeg aktivnog sudjelovanja u tom procesu neće ni dogoditi. Potrebno je, dakle, s Bogom surađivati u ekumenskim procesima, a Bog će ostalo nadodati i nadopuniti kako bi ovaj proces proveo u svome konačnom ispunjenju.

Kroz isticanje nekoliko važnih doprinosa Katoličke Crkve ekumenizmu, u ovom radu želimo, ne zaboravljajući istovremeno da ih nismo sve spomenuli i iscrpili, pružiti i opravdati pozitivan stav prema ekumenskom nastojanju te, također, potaknuti ponajprije katolike, a onda i druge kršćane iz svih slojeva Crkava i crkvenih zajednica, da se i osobno uključe u ekumenske procese kako bismo doprinijeli bržem ostvarenju toliko željenog cilja, a to je vidljivo jedinstvo Kristovih učenika. Mnogo je toga na ovom putu do naših dana učinjeno. Mnogo je toga što nas još očekuje. Zadatak je svakog kršćanina da se u taj proces aktivno uključi, a to će moći jedino ako se oduševi i zdušno prihvati ovaj proces kao dio svog identiteta te ga kao takvog bude živio. Da bi to bilo lakše, potrebno je naglasiti važne korake i doprinose Katoličke Crkve te ulogu nekih istaknutih ekumenskih djelatnika na ovome putu, a što je zadatak ovoga rada. 


\section{Molitvena osmina za jedinstvo kršćana}

Možemo reći kako je molitvena osmina za jedinstvo kršćana, a moli se od 1908. godine, starija od službenog početka suvremenog ekumenskog pokreta, a koji službeno započinje 1910. godine, kada je u škotskom Edinburghu sazvana prva Svjetska misijska konferencija. Ipak, i prije 1908. godine postojala su različita nastojanja da se uvede zajednička molitva za jedinstvo kršćana te samim time njezini korijeni sežu puno dalje u prošlost. Tako se oko 1740. godine u Škotskoj pojavljuje pokret koji je pozivao na obnovu vjere na način da se sve Crkve uključe u molitvu. Sto godina kasnije, 1840. godine, Ignatius Spencer (1799. - 1864.) predložio je Savez molitve za jedinstvo. Nadalje, 1867. godine Prva konferencija anglikanskih biskupa $\mathrm{u}$ Lambethu u završnoj Rezoluciji naglašava potrebu molitve za jedinstvo. Godine 1894. papa Lav XIII. potiče praksu molitvene osmine za jedinstvo kršćana i to u okviru blagdana Duhova. On je propisao molitve za ponovno ujedinjenje rastavljene braće svih onih koji su se odvojili od Katoličke Crkve. Konačno 1908. godine uvedena je molitvena osmina u mjesecu siječnju te se ona održava sve do danas ${ }^{1}$.

Molitvena osmina za jedinstvo kršćana slavi se od 18. do 25. siječnja svake godine, a ovo je vremensko razdoblje predložio o. Paul F. Wattson (1863. - 1940.), koji se ujedno smatra i utemeljiteljem molitvene osmine za jedinstvo podijeljenih kršćana. Namjera je bila da obuhvati razdoblje između blagdana Katedre svetoga Petra (nakon liturgijske reforme u Katoličkoj Crkvi slavi se 22. veljače) te blagdana Obraćenja svetoga Pavla. Ova dva blagdana imaju i svoje simbolično značenje. Naime, blagdan Katedre sv. Petra označavao je konačni cilj ove molitve: jedinstvo kršćana u zajedništvu s apostolskim prvakom sv. Petrom i njegovim nasljednicima. Drugi blagdan odnosi se na način postizanja jedinstva, a ono glasi: obraćenje Kristu. Primjer obraćenja sv. Pavla kod Damaska izvrstan je primjer toga. Na južnoj Crkvenoj hemisferi molitvenu osminu redovito prakticiraju najčešće oko blagdana Duhova, a to je već 1926. godine preporučio pokret Vjera i ustrojstvo. Blagdan Duhova također je bogat simbolikom. Naime, Duh Sveti onaj je po kojem se ostvaruje i vrši u Bogu jedinstvo².

Papa Benedikt XV. 1916. godine preporučio je ovu molitvu svim katolicima. Također joj je papa Pio XII. bio sklon te je pozivao katolike da se uključe.

Budući da je Wattson shvaćao ekumenizam u predkoncilskom duhu, a što je sasvim bilo u duhu ondašnjeg vremena i u skladu s općim razmišljanjem u Katoličkoj Cr-

\footnotetext{
${ }^{1}$ Usp. J. ZEČEVIĆ, Nastanak, povijest i smisao tjedna molitve za jedinstvo kršćana, u: Bogoslovska smotra 65(1996.)2, 229.-231.

${ }^{2}$ Usp. PAPINSKO VIJEĆE ZA PROMICANJE JEDINSTVA KRŠĆANA - POVJERENSTVO »VJERA I USTROJSTVO « EKUMENSKOG VIJEĆA CRKAVA, Molitvena osmina za jedinstvo kršćana 2017. godine, Zagreb, 2016., 4.
} 
kvi, lako je moguće razumjeti i njegovu namjeru s obzirom na molitvenu osminu i njezino smještanje između ova dva blagdana. Ipak, to nikako ne umanjuje značaj ove molitvene osmine koja će kasnije zadobiti svoje puno i pravo značenje: zajednička molitva te zajedničko obraćenje svih razjedinjenih kršćana i povratak svih Kristu. Tek je Paul Couturier (1881. - 1953.) uspio doprinijeti tome da se više ne moli za povratak odijeljenih kršćana u krilo Katoličke Crkve, nego da svi zajedno mole za jedinstvo za koje je već Isus Krist na Posljednjoj večeri žarko molio, da svi budu jedno (usp. Iv 17). Od 1966. godine molitvenu osminu za jedinstvo kršćana zajedno pripremaju Tajništvo za jedinstvo kršćana te odbor za Vjeru i ustrojstvo Ekumenskog vijeća Crkava, i to izabirući teme i pripremajući materijale za svaku godinu posebno ${ }^{3}$.

Zašto je ova molitvena osmina važna za Katoličku Crkvu i ekumensko djelovanje? Ponajprije, potrebno je istaknuti kako je u apsolutnoj većini katoličkih župa i župnih zajednica ova molitvena osmina za jedinstvo kršćana jedina ekumenska aktivnost kroz cijelu liturgijsku godinu, iako se i ta aktivnost uglavnom odvija bez predstavnika drugih Crkava i crkvenih zajednica. Ona je često jedini događaj u katoličkim župnim i drugim zajednicama koji u sebi uključuje i ekumensku dimenziju te se preko ove molitvene osmine može i treba senzibilizirati katoličke zajednice za ekumenizam. Prihvaćanjem ove molitvene osmine i svojim aktivnim uključivanjem Katolička Crkva učinila je veliki korak u osvješćivanju svojih vjernika o postojanju ekumenizma te o potrebi da svatko na tome putu nešto i učini. Molitva za jedinstvo svakako je nešto čime svaki katolik može doprinijeti konačnom postizanju ekumenskog cilja, a to je vidljivo jedinstvo Kristovih učenika. Nadalje, ova molitvena osmina, ako se prihvati u njezinom pravom duhu, a to je zajednička molitva razjedinjenih kršćana, može itekako osvijestiti katolicima da, iako u Katoličkoj Crkvi opstoji (subsistit in) Kristova Crkva, ipak ona nije jedina i ekskluzivna zajednica koja se može u potpunosti identificirati s Kristovom Crkvom te da postoje i drugi

\footnotetext{
${ }^{3}$ U 2017. godini u molitvenoj osmini naglasak je stavljen na 500 godina od početka Reformacije. Da je i ovu važnu obljetnicu i važan korak prema međusobnom približavanju moguće krivo shvatiti, svjedoči nam i tekst Snježane Majdandžić-Gladić pod naslovom Puzajući katolicizam i sinkretistički ekumenizam u kojem, između ostaloga, piše: »Taj dokument u mnogim svojim dijelovima baca sjene na dobronamjernost ekumenskih zbivanja i bit će poželjno da ih hrvatski priređivač javno otkloni, posebno s obzirom na činjenicu da se u Hrvatskoj zadnjih godina provodi otvorena protestantizacija Katoličke Crkve, a u čijim se prvim redovima nalaze i neki vrlo medijski popraćeni i slavljeni katolički svećenici«. https://www.vjeraidjela.com/puzajuci-katolicizam-i-sinkretisticki-ekumenizam/ (21. III. 2017). U cijelom ovom tekstu autorica pokazuje svoje nepoznavanje temeljnih ekumenskih principa te nepoznavanje ekumenizma u njegovoj biti. Ona radije nastupa kao apologet, braneći stajališta koja se u službenim krugovima u Katoličkoj Crkvi rijetko zastupaju te ih možemo nazvati u najmanju ruku pogrešnima.
} 
kršćani koji su naša braća i sestre, a nikako suparnici ili otpadnici koje bi bilo potrebno preobratiti i vratiti u krilo Katoličke Crkve.

Smatramo iznimno važnim ovo katoličko uključivanje, a još važnijim ispravno shvaćanje molitve za jedinstvo kršćana kao zajedničke molitve Bogu u Isusu Kristu i Duhu Svetomu. Gdje god postoji isključivanje drugih, pogrešni ekskluzivizam, zavaravanje samih sebe, uvjeravajući se u vlastitu ispravnost dok su svi drugi u krivu i sl., postoji velika i stvarna opasnost od razvijanja različitih ekstremističkih stavova i mišljenja koji nikako ne doprinose međusobnom pomirenju i približavanju, nego postižu suprotan učinak. Nadalje, postoji opasnost da se ekumenizam smatra zabludom ili pak nečim što ionako nema nikakvog smisla te se umnožava grupa kritičara i pesimista koji u odnosu na ekumenska gibanja zauzimaju negativne stavove i takve šire među drugim katolicima. Ispravno shvaćanje te uključivanje Katoličke Crkve u molitvenu osminu za jedinstvo kršćana itekako je važan korak u krilu iste Crkve, kojim se uspijeva razvijati ispravan duh i kojim se doprinosi ponovnom ujedinjenju razjedinjenih kršćana.

\section{Drugi vatikanski sabor}

Kada je riječ o Drugom vatikanskom saboru i doprinosu promjeni katoličkog stava prema ekumenizmu, ne može se dovoljno naglasiti njegova iznimna važnost. Naime, odnos Katoličke Crkve prema ekumenizmu dijeli se na vrijeme prije i nakon Drugog vatikanskog sabora ${ }^{4}$, u kojem razdoblje prije karakterizira odbijanje sudjelovanja u ekumenskim gibanjima, smatrajući taj pokret nečim duboko pogrešnim, dok razdoblje nakon Sabora karakterizira vrlo živa zauzetost i uključivanje u ekumenske procese na svim razinama, do te mjere da je papa Ivan Pavao II. napisao kako ekumenizam nije privjesak, nego bit Crkves .

\footnotetext{
${ }^{4}$ Ne slažemo se s relativiziranjem protestantskog doprinosa ekumenizmu općenito i ekumenskom pokretu u njegovom nastajanju u smislu da pripisati nastanak ekumenizma protestantskim crkvama znači »neekumensko ophođenje s pojmom ekumenizma « te da ta činjenica »povećava rezerviranost i odbojnost prema ekumenizmu u drugim Crkvama «. J. ZEČEVIĆ, Koncilski ekumenski zamah i današnja traženja, u: Bogoslovska smotra 75(2006.)3, 860. Ako se 1910. godina uzme kao službeni početak ekumenskog pokreta, onda je sasvim jasno da Katolička Crkva u njemu nije sudjelovala. Osim toga, jasno je i to da je predkoncilski ekumenizam u Katoličkoj Crkvi obilježen izrazitim odbijanjem bilo kakvog sudjelovanja i zabranjivanjem katolicima da u njemu sudjeluju. Dovoljno je pročitati encikliku Pija XI., pod naslovom Mortalium animos (1928.) da se stekne uvid u stanje prije Drugog vatikanskog sabora u odnosu na ekumenizam. U tom smislu Drugi vatikanski sabor uistinu predstavlja novost i može ga se nazvati kopernikanskim obratom u odnosu na ekumenizam i promjene svijesti o važnosti ekumenizma.
}

${ }^{5}$ Usp. IVAN PAVAO II., Ut unum sint, Zagreb, 1995., br. 20. 
Mnogo je toga važnog što se na Drugom vatikanskom saboru dogodilo, a što je, bilo izravno bilo neizravno, odigralo odlučujuću ulogu u promjeni smjera Katoličke Crkve u odnosu na ekumenizam ${ }^{6}$. Istaknut ćemo samo nekoliko najvažnijih elemenata.

\subsection{USMJERENOST NA EKUMENIZAM}

Drugi vatikanski sabor bio je u svom temelju ekumenski usmjeren. Naime, istina je da ovaj Sabor nije imao za cilj postizanje jedinstva kršćana. Međutim, istina je također da se od samog sazivanja pa kroz cijeli njegov rad, a posebice u službenim dokumentima, ekumenizam provlači kao crvena nit koja sve povezuje. Papa Ivan XXIII. (1881. - 1963.) u enciklici Ad Petri Cathedram (20. lipnja 1959.) piše kako Sabor mora biti i za kršćane nekatolike poziv da traže i postignu ono jedinstvo za koje je Isus Krist svoga Oca žarko molio (usp. Iv 17) ${ }^{7}$. Nadalje, spomenimo i apostolsku konstituciju Humanae salutis, u kojoj je na Božić 1961. godine i najavljen Drugi vatikanski sabor na kojem papa Ivan XXIII. doslovno kaže: »Na koncu pozivamo sve kršćane odijeljene od Katoličke Crkve neka mole Boga, da bi Sabor bio koristan i za njih. Znamo da mnogi od ovih sinova gaje želju da se postigne jedinstvo i mir, prema Kristovoj nauci i molitvi od njega upravljenog Ocu. Znamo, također, da je najava Sabora od njih ne samo primljena s velikom radošću nego da su mnogi od njih obećali moliti Boga za njegov dobar i sretan ishod $\ll^{8}$.

Očito je kako je ova nakana pape Ivana XXIII. da Sabor bude ekumenski usmjeren uvelike utjecala i oblikovala budući rad koji se u različitim fazama na Saboru i odvi-

\footnotetext{
${ }^{6}$ Donald W. Norwood tvrdi da Katolička Crkva nikad nije bila više $\gg$ katolička $<$ nego na Drugom vatikanskom saboru te da oni koji nisu katolici, dakle anglikanci, protestanti, pentekostalci, ne mogu prihvatiti da je ovaj sabor bio 21. ekumenski koncil u nastavku koncila u Niceji 325. i Carigradu 381. godine. Usp. D. W. NORWOOD, Vatican II. The most Catholic Council?, u: The Ecumenical Review 66(2014.)4, 421.

7 \Norunt profecto omnes Divinum Redemptorem talem condidisse societatem, quae una esset ad obitum usque saeculorum, secundum illud: 'Ecce ego vobiscum sum omnibus diebus usque ad consummationem saeculi'; et hac de causa ad caelestem Patrem incensissimas adhibuisse preces. Haec autem Iesu Christi precatio, quae accepta profecto fuit, et exaudita pro sua reverentia: 'Ut omnes unum sint, sicut tu, Pater, in me, et ego in te, ut et ipsi in nobis unum sint' $\ll$. IVAN XXIII., Litterae encyclicae Ad Petri cathedram, u: Acta Apostolicae Sedis 51(1959.)1, 510.-511.

8 »Extremum christianos omnes qui a catholica Ecclesia dissident enixe rogamus, ut Deo supplicent: nam ad eorum etiam fructum Concilium redundabit. Nos enim minime latet ex his filiis complures unitatis et pacis assequendae desiderio teneri, iuxta Christi doctrinam, iuxtaque precationem ab eo caelesti Patri admotam; neque Nos praeterit, auditum Concilii nuntium non solum magno gaudio ab iis esse acceptum, verum etiam ex iis haud paucos pollicitus esse se precaturos Deum, ut res bene ac feliciter eveniat, et laeta in spe esse suorum Coetuum nomine mitti posse legatos, qui de iis certiores fiant, quae in Concilio agantur «. IVAN XXIII., Constitutio apostolica Concilium Oecumenicum Vaticanum II indicitur Humanae salutis, u: Acta Apostolicae Sedis 54(1962.) 1, 12.
} 
jao, a što se na koncu potvrdilo i u izglasavanju dokumenta koji je posvećen izričito ekumenizmu pod nazivom Unitatis redintegratio. Ako se zanemari ekumenizam, smatramo kako se dokumente Sabora i njegov duh ne može u potpunosti ispravno razumjeti. Ispravno proučavanje saborskih dokumenata uvelike ovisi o tome jesmo li dobro shvatili saborsku temeljnu ekumensku usmjerenost koja se postupno za vrijeme odvijanja Sabora otkrivala te na koncu jasno došla do izražaja.

\subsection{TAJNIŠTVO ZA SJEDINJENJE KRŠĆANA}

Ekumenska usmjerenost Sabora jasno se pokazala i u osnivanju, prvi put u povijesti Katoličke Crkve, Tajništva za sjedinjenje kršćana, a koje je, na poticaj kardinala Augustina Bee (1881. - 1968.), osnovano motuproprijem pape Ivana XXIII., pod naslovom Superno Dei nutu' ${ }^{9}$ i to na blagdan Duhova dana 5. lipnja 1960. godine. Neki stručnjaci smatraju kako je upravo ustanovljenjem ovog Tajništva za sjedinjenje kršćana započela i službena uključenost Katoličke Crkve u ekumenski pokret, a koja je danas zasigurno glavni pokretač i podupiratelj ekumenskih zbivanja u cijelom svijetu. Njegova je zadaća, kako i sam naslov kaže, sjedinjenje s drugim kršćanima, a to će se ostvariti, bilo kroz bilateralne bilo kroz multilateralne kontakte s kršćanskom braćom u drugim Crkvama i crkvenim zajednicama.

Da je ovo tajništvo važno za Katoličku Crkvu, svjedoči nam i činjenica da je i nakon završetka Drugog vatikanskog sabora nastavilo postojati. Danas djeluje pod naslovom Papinsko vijeće za promicanje jedinstva kršćana te ima odlučujuću ulogu u održavanju ekumenskog smjera cijele Katoličke Crkve.

\subsection{Prisutnost NeKatoličKih promatrača na Saboru}

Kada je riječ o nekatoličkim promatračima na Drugom vatikanskom saboru, onda razlikujemo promatrače delegate, koji su bili službeni delegati svojih Crkava i crkvenih zajednica, od promatrača gostiju, koji su bili pozvani od Tajništva za sjedinjenje kršćana. Iako nisu imali formalnu ulogu na Saboru, u smislu da su mogli glasovati ili pak aktivno sudjelovati u saborskim raspravama o pripremljenim shemama, ipak su imali itekako važnu ulogu u održavanju samog Sabora. Naime, promatrači su dobivali iste pripremne sheme kao i saborski oci te su ih mogli izvan Sabora komentirati i o njima raspravljati. Tako su promatrači sudjelovali na sjednicama sabora, tzv. generalnim skupštinama, ali su imali i različite sastanke, susrete, konferencije za novinare gdje su raspravljali o važnim događajima na Saboru te tako stalno bili, u određenom smislu, ekumenski glas savjesti saborskim Ocima.

\footnotetext{
9 IVAN XXIII., Litterae apostolica. Moru proprio datae. Commissiones concilio vaticano secundo apparando instituuntur. Superno Dei nutu, u: Acta Apostolicae Sedis 52(1960.)7, 433.-437.
} 
Najvažniji trenutak sudjelovanja nekatoličkih promatrača na Saboru bio je u trenutku kada se raspravljalo o shemi De oecumenismo. Ovim dokumentom saborski su Oci trebali iskazati svoju viziju ekumenizma i koja je uloga Katoličke Crkve u tom ekumenskom procesu. Promatrači su očekivali da saborski Oci zauzmu svoj stav jer bi službeni stav Sabora, potpisan od pape, značio početnu točku za razgovore i eventualno uključivanje Katoličke Crkve u ekumenizam ${ }^{10}$. Jedan od najpoznatijih promatrača na Saboru, protestantski egzeget i ekumenski teolog Oscar Cullmann (1902. - 1999.), u vezi sa shemom De oecumenismo, na jednoj od sjednica promatrača na Saboru, rekao je kako je ona iznimno važan trenutak i da se oni kao protestanti nadaju jednom novom pristupu Katoličke Crkve samom ekumenizmu i drugim kršćanima ${ }^{11}$.

\subsection{NOVI PRISTUP EKUMENIZMU - »UNITATIS REDINTEGRATIO $\ll$}

Novi pristup ekumenizmu, koji su toliko željeli nekatolički promatrači na Saboru, izražen je u saborskom dekretu o ekumenizmu pod naslovom Unitatis redintegratio. Dekret je izglasan 21. studenoga 1964. godine s apsolutnom većinom glasova. Iako je ovo jedini dokument na Saboru koji je u potpunosti posvećen ekumenizmu, ne može se nikako tvrditi da je i jedini saborski dokument u kojem se govori o toj važnoj temi ${ }^{12}$. Naime, i u drugim dokumentima nalazimo pojedine dijelove koji su nadahnuti ekumenizmom, kao što je dogmatska konstitucija o Crkvi Lumen gentium, dogmatska konstitucija o božanskoj objavi Dei verbum, Dekret o Istočnim katoličkim Crkvama Orientalium Ecclesiarum itd. Svakako, ovo je prvi sabor u Katoličkoj Crkvi koji je donio jedan dokument koji je u potpunosti posvećen ekumenizmu te ga i iz tog razloga možemo smatrati izrazito važnim korakom na ekumenskom putu Katoličke Crkve, a onda posljedično važnim i za ostale Crkve i crkvene zajednice uključene u ove ekumenske procese, kako na svjetskoj tako i na lokalnoj razini.

\section{5. $\gg$ SUBSISTIT IN $\ll$}

Izrazito važan ekumenski korak učinila je Katolička Crkva na Drugom vatikanskom saboru upotrebljavajući izraz subsistit in (opstoji u, nalazi se u). Krist je na zemlji

\footnotetext{
${ }^{10}$ Usp. I. MACUT, Oscar Cullmann e il concilio vaticano II, u: Protestantesimo 67(2012.)2, 250.-251.

${ }^{11}$ Usp. A. MELLONI (ur.), Storia del concilio Vaticano II, vol. III: Il Concilio adulto. Il secondo periodo e la seconda intersessione settembre 1963 - settembre 1964, Bologna, 1998., 311.

${ }^{12}$ Bibliografija koja govori o ovom saborskom dokumentu te ga u potpunosti ili djelomično tumači i više je nego obilna te ju je nemoguće nabrojati. Ovdje ćemo spomenuti samo jedan klasični komentar na talijanskom jeziku te jedan na hrvatskom jeziku: G. CERETI, Commento al decreto sull'ecumenismo. Per rivivere le riflessioni e le speranze dell'epoca conciliare, Verona, 2013.; M. LACKO, R. PERIĆ, Dekret o ekumenizmu Unitatis redintegratio. Dekret o Istočnim katoličkim Crkvama. Komentari dokumenata Drugog vatikanskog sabora 5., Zagreb, 1987.
} 
ustanovio jednu Crkvu i ona se nalazi u Katoličkoj Crkvi, a kojom upravljaju nasljednik apostola Petra i biskupi sjedinjeni s njim. Ovo postojanje označava trajni povijesni kontinuitet i zadržavanje svih elemenata koje je Krist ustanovio u Katoličkoj Crkvi, u kojoj se stvarno nalazi Kristova Crkva na ovoj zemlji ${ }^{13}$. U stvarnosti izričaj subsistit in ne mijenja tradicionalni nauk o Katoličkoj Crkvi. Ipak, njime se mnogo jasnije očituje kako izvan Katoličke Crkve nije nekakva crkvena praznina, u smislu da nema crkvenosti, nego se i izvan nje nalaze mnogi elementi posvećenja i istine, a koji su kao darovi svojstveni Kristovoj Crkvi te potiču na katoličko jedinstvo $^{14}$.

Možemo reći kako je identifikacija između Katoličke Crkve i Crkve Kristove u dogmatskoj konstituciji o Crkvi Lumen gentium i u ovom izričaju zadržana, ali ne ekskluzivno u smislu odbijanja postojanja crkvenosti i izvan granica Katoličke Crkve, nego se priznaje postojanje određenih elemenata ${ }^{15}$. Ne ulazeći dublje u razradu ovog saborskog izričaja, ovdje je samo potrebno istaknuti kako se tim izrazom potvrđuje da se i izvan vidljivih granica Katoličke Crkve mogu naći važni eklezijalni elementi: pisana Riječ Božja, život milosti, vjera, nada itd. ${ }^{16}$.

Da ovaj izričaj ima iznimnu važnost za ekumenizam, nije moguće dovoljno naglasiti. Od izrazito ekskluzivističke ekleziologije koja se protezala do Drugog vatikanskog sabora, došli smo do priznavanja ne samo mogućnosti nego i stvarnog postojanja elemenata crkvenosti i izvan granica Katoličke Crkve. Ova nova saborska perspektiva otvara velike ekumenske mogućnosti te se približavanje u različitim ekleziologijama mora odvijati uvažavajući ovu novu stvarnost. Ovo je, nadalje, i znak drugim Crkvama i crkvenim zajednicama da je na području ekleziologije potrebno odreći se izrazitog ekskluzivizma te priznati i drugima barem određene elemente crkvenosti, a što onda treba pomoći za buduću izgradnju jedne, što više

13 »2. Quaeritur: Quomodo intellegendum sit Ecclesiam Christi subsistere in Ecclesia Catholica? [... Subsistentia in Constitutione Dogmatica Lumen gentium est haec perpetua continuatio historica atque permanentia omnium elementorum a Christo in stitutorum in Ecclesia catholica, in

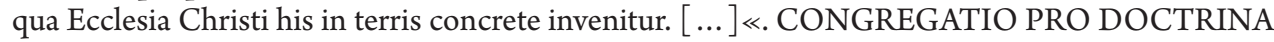
FIDEI, Responsa ad quaestiones de aliquibus sententiis ad doctrinam de Ecclesia pertinentibus, $\mathrm{u}$ : Acta Apostolicae Sedis 99(2007.)7, 606.

14 »3. Quaeritur: Quare vocabulum 'subsistit in' et non simpliciter verbum 'est' adhibetur? Respondetur: Usus vocabuli retinentis plenam identitatem Ecclesiae Christi et Ecclesiae Catholicae doctrinam de Ecclesia non immutat, rationem tamen habet veritatis, apertius significans quod extra eius compaginem 'elementa plura sanctificationis et veritatis' inveniuntur, 'quae ut dona Ecclesiae Christi propria ad unitatem catholicam impellunt' «. CONGREGATIO PRO DOCTRINA FIDEI, Responsa ad quaestiones de aliquibus sententiis ad doctrinam de Ecclesia pertinentibus, 607.

${ }^{15}$ Usp. A. MAFFEIS, Il dialogo ecumenico, Brescia, 2000., 56.

${ }^{16}$ Usp. N. IKIĆ, Communio i Successio u teologiji Petrove službe, u: Diacovensia 22(2014.)2, 219.231., 221. 
zajedničke, ekleziologije. Koliko god to bio težak zadatak, ipak je od presudne važnosti o njemu govoriti i na njemu raditi.

\section{6. $\gg$ HIERARCHIA VERITATUM $\ll$}

U dekretu o ekumenizmu Unitatis redintegratio u br. 11, Drugi vatikanski sabor ustanovio je kako među istinama katoličke vjere postoji određena hijerarhija jer je različit njihov odnos prema temeljnim istinama kršćanske vjere ${ }^{17}$. Ova je saborska tvrdnja važna za ekumenski dijalog ${ }^{18}$ jer otvara nove perspektive u razgovoru s drugim kršćanima. Tako je protestantski teolog Oscar Cullmann ovaj 11. paragraf Unitatis redintegratio ocijenio najrevolucionarnijim na cijelom Saboru: »Smatram ovaj paragraf najrevolucionarnijim koji je moguće pronaći, ne samo u dokumentu o ekumenizmu nego i u bilo kojem drugom dokumentu predstavljenom na Saboru. U skladu s tekstom bit će moguće rasporediti dogme kao što su Petrov primat i Marijanske dogme na različita mjesta s obzirom na dogme o Kristu i Trojstvu $\ll^{19}$.

Saborski su Oci utvrdili kako nisu sve istine (dogme) vjere u jednakom odnosu prema središnjim istinama kršćanske vjere ${ }^{20}$, kao što se to ranije tvrdilo. Naime, postoje određene vjerske istine koje su važne, ali koje imaju nešto manju važnost (npr. dogma o Marijinu uznesenju na nebo) u odnosu na povezanost s temeljem kršćanske vjere. Smatramo kako se ovim izričajem nikako ne želi zanijekati važnost »manje važnih « istina vjere, nego se samo želi istaknuti da postoji određeni red vjerskih istina te da ih katolici priznaju i kao takve prihvaćaju ${ }^{21}$. Osim toga, ovu saborsku tvrdnju ne smije se shvatiti u smislu relativiziranja određenih vjerskih istina.

$17 \gg$ In comparandis doctrinis meminerint existere ordinem seu 'hierarchiam' veritatum doctrinae catholicae, cum diversus sit earum nexus cum fundamento fidei christianae «. DRUGI VATIKANSKI KONCIL, Unitatis redintegratio, Zagreb, 2008., br. 11.

${ }^{18}$ Jedan od prvih katoličkih istraživača saborskog izričaja »hijerarhija istina « u ekumenskom duhu bio je H. MÜHLEN, Die Lehre des Vaticanim II über die <hierarchia veritatum> und ihre Bedeutung für den ökumenischen Dialog, u: Theologie und Glaube 56(1966.), 303.-335.

${ }^{19}$ O. CULLMANN, Comments on the decree on ecumenism, u: The Ecumenical review 17(1965.)2, 94.-95. Vidi još i O. CULLMANN, Sind unsere Erwartungen erfült?, u: K. RAHNER, O. CULLMANN, H. FRIES (ur.), Sind die Erwartungen erfült? Überlegungen nach dem Konzil, München, 1966., 33.-66.; U. VALESKE, Hierarchia veritatum. Theologiegeschichtliche Hintergründe und mögliche Konsequenzen einer Hinweises im Ökumenismusdekret des II. Vatikanischen Konzil zum zwischenkirchlichen Gespräch, München, 1968.

${ }^{20} \mathrm{O}$ odnosu dogme i vjere u ekumenskom duhu vidi: H. FILSER, Dogma, Dogmen, Dogmatik. Eine Untersuchung zur Begründung und zur Entstehungsgeschichte einer theologischen Disziplin von der Reformation bis zur Spätaufklärung, Münster-Hamburg-Berlin-London, 2001.

${ }^{21} \mathrm{O}$ protestantskom shvaćanju i o kratkoj raspravi o »hijerarhiji istina « na Drugom vatikanskom saboru vidi: I. MACUT, Ograničenja i novosti II. vatikanskog sabora prema Oscaru Cullmannu, u: Služba Božja 51(2011.)1, 56.-74. 
Izričaj »hijerarhija istina « prije treba shvatiti u smislu stavljanja svih vjerskih istina u odnos s temeljem kršćanske vjere, a samim time i u njihov međusobni odnos.

Nakon Drugog vatikanskog sabora dosta se o ovoj tematici govorilo te je postignut i zajednički dokument pod naslovom Pojam $\gg$ hijerarhije istina $\ll-e k u m e n s k a$ interpretacija i to 1990 . godine ${ }^{22}$, a dokument su izradile radne skupine Katoličke Crkve i Ekumenskog vijeća Crkava.

\section{Uključivanje u pokret $\gg V j e r a$ i ustrojstvo«}

Jedan od najvažnijih elemenata u povijesti Crkve u 20. stoljeću zasigurno je ekumenski pokret ${ }^{23}$. Godine 1927. sazvana je i prva Svjetska konferencija za vjeru i ustroj Crkve (Faith and Order) u Lausanni (Švicarska). Veliki pokretač i zastupnik ovog pokreta bio je Charles Brent (1862. - 1929.) koji je sudjelovao na Misijskoj konferenciji 1910. godine u Edinburghu. Ovaj je pokret nastao zbog mišljenja kako »praktični ekumenizam«(Life and Work) neće imati većeg uspjeha, ako se ne bude paralelno razgovaralo i pokušavalo riješiti doktrinarna pitanja. Zbog toga se organiziraju i svjetske konferencije gdje se raspravlja o misijskoj službi Crkve, o posvećenju, ekleziologiji, hijerarhiji itd., te se želi postići što je moguće veće suglasje, a što se posebno očituje u ekumenskim dokumentima ${ }^{24}$.

Nakon Drugog vatikanskog sabora Katolička se Crkva aktivno uključuje u pokret ili komisiju Vjera i ustrojstvo i to od 1968. godine, iako nije član Ekumenskog vijeća Crkava ${ }^{25}$. Počinju se voditi bilateralni i multilateralni razgovori između katolika, pravoslavaca, luterana, anglikanaca itd. Od dokumenata koje je potrebno spomenuti svakako je važno istaknuti dva: Dokument iz Lime ili Dokument o krštenju, euharistiji i ministeriju, nazvan BEM (Baptism, Eucharist, Ministry) ${ }^{26}$, iz 1982. godine, te dokument pod naslovom Crkva: prema jednoj zajedničkoj viziji iz 2012. godine, a za koji komisija Vjera i ustrojstvo očekuje da će imati istu važnost kao i

${ }^{22}$ Der Begrif der 'Hierarchie der Wahrheiten' - eine ökumenische Interpretation, u: Una Sancta 45 (1990.), 262.-270.

${ }^{23}$ Usp. R. KOTTJE, B. MOELLER, Ekumenska povijest Crkve 3. Novi vijek i moderno doba, Zagreb, 2008., 310.

${ }^{24}$ Usp. D. MORO, Hod ekumenizma u XX. stoljeću. Konferencije »Vjere i ustrojstva «, protagonisti, poteškoće, Split, 2009., 13.-14.

${ }^{25} \mathrm{O}$ razlozima zašto Katolička Crkva nije član Ekumenskog vijeća Crkava ukratko se može vidjeti u: J. ERNESTI, Breve storia dell'ecumenismo. Dal cristianesimo diviso alle Chiese in dialogo, Bologna, 2010., 104.-105.

${ }^{26} \gg$ Ovaj dokument, s velikim nadama koje probuđuje od svog nastanka, nema učiteljsko značenje, ali nudi jednu fotografiju stanja ekumenske refleksije o tri iznimno važna aspekta za život Crkve «. R. BURIGANA, Una straordinaria avventura. Storia del Movimento ecumenico in Italia (1910-2010), Bologna, 2013., 138. 
onaj iz Lime ${ }^{27}$. Ova dva dokumenta - iako ih je otkako se Katolička Crkva uključila u Komisiju Vjera i ustrojstvo nastalo mnogo više - predstavljaju iznimno važan doprinos, a posebice tzv. Dokument iz Lime, koji je »vjerojatno najznačajniji ekumenski teološki sporazum ne samo u okviru Ekumenskog vijeća Crkava [...] nego je jedan od najzanimljivijih konvergentnih tekstova na teološkom kršćanskom polju od istočnog ili zapadnog raskola do danas $\ll^{28}$. S obzirom na drugi dokument koji smo istaknuli pod naslovom Crkva: prema jednoj zajednickoj viziji, komisija Vjera $i$ ustrojstvo u njega polaže velike nade, izražavajući, kako smo već rekli, da ima isto značenje kao i dokument iz 1982. godine. O tolikoj važnosti ovog dokumenta još je rano govoriti. Ipak neki teolozi, poput talijanskog teologa Marija Farcija, smatraju kako ovaj dokument želi biti jedna platforma na kojoj će se kasnije razviti ne samo ekumenska rasprava nego i refleksije te istraživanje pojedinih Crkava, tj. magna charta na kojoj će se Crkve kasnije nadahnjivati u svojim promišljanjima ${ }^{29}$.

Koliko će Crkve i crkvene zajednice ovaj dokument iz 2012. godine ozbiljno prihvatiti, pokazat će njihovi službeni odgovori. Osim toga, potrebno je pričekati da se vide i eventualne promjene koje će Crkve pokrenuti, zahvaljujući upravo ovom dokumentu i njegovim poticajima. Kada je riječ o važnosti dokumenta, onda možemo reći kako je ona u tome što on na jednome mjestu sažima dosadašnji ekumenski put i to s obzirom na ekleziološku tematiku. Uz to osvješćuje Crkvama probleme o kojima bi trebale razmišljati te ih potiče da ponude zadovoljavajuće odgovore koji bi onda posljedično potaknuli i brže i učinkovitije približavanje i ujedinjavanje razjedinjenih kršćana. Ipak, osobno smo mišljenja kako ne treba očekivati spektakularne rezultate, kao što je to bilo is dokumentom iz 1982. godine, jer se u ekumenskom približavanju sporo napreduje, što je pogotovo slučaj kad je riječ o vrlo teškim ekumenskim problemima, a problemi koji se obrađuju u ovom dokumentu zasigurno to i jesu ${ }^{30}$.

Dokument jasno pokazuje da problemi s obzirom na Crkvu u cjelini, a to su Sveto pismo, Tradicija itd., i dalje postoje, ali, kako to ističe kardinal Walter Kasper, oni se sada promatraju u jednom potpuno novom svjetlu ${ }^{31}$.

\footnotetext{
${ }^{27}$ Više o ovom dokumentu vidi: I. MACUT, »Prema zajedničkoj viziji Crkve «. Teološko značenje i problematika dokumenta komisije »Vjera i ustrojstvo «, u: Crkva u svijetu 50(2015.)1, 160.-179.

${ }^{28}$ R. PERIĆ, Tajna krštenja u dosadašnjem ekumenskom dijalogu, u: Bogoslovska smotra 61(1991.)1$2,13$.

${ }^{29}$ Usp. M. FARCI, Il testo di convergenza La Chiesa: verso una visione comune e la successione apostolica nel ministero, u: Studi ecumenici 32(2014.), 59.

${ }^{30}$ Usp. I. MACUT, »Prema zajedničkoj viziji Crkve «. Teološko značenje i problematika dokumenta komisije $\gg$ Vjera i ustrojstvo $\ll, 175$.

${ }^{31}$ Usp. W. KASPER, Das Gespräch mit der protestanischen Theologie, u: ISTI, Wege zur Einheit der Christen. Schriften zur Ökumene I, G. Augustin, Klaus Krämer (ur.), Freiburg-Basel-Wien, 2012., 240.
} 


\section{Dokumenti Zajednička izjava o opravdanju (1999.) i Od sukoba do zajedništva (2013.)}

Na koncu nabrajanja važnih koraka na ekumenskom putu Katoličke Crkve smatramo potrebnim istaknuti dva dokumenta: Zajednička izjava o opravdanju (1999.), koju su u Augsburgu 31. listopada 1999. potpisali predstavnici Katoličke Crkve i Svjetskog luteranskog saveza te dokument Od sukoba do zajedništva (2013.), plod rada Luteransko-katoličke komisije.

Kada je riječ o dijalogu između luterana i katolika, tema o opravdanju od iznimne je važnosti. Naime, Luther i drugi reformatori smatrali su to prvim i temeljnim člankom vjere koji je odlučujući za cjelokupno kršćansko učenje ${ }^{32}$. Osim toga, i papa Franjo, dana 31. listopada 2016. prigodom posjeta Lundu ${ }^{33}$ i na otvaranju obilježavanja 500-te obljetnice od početka Reformacije, rekao je: »Učenje o opravdanju, dakle, izriče bit ljudske egzistencije u odnosu prema Bogu $\ll^{34}$. U dokumentu $O d$ sukoba do zajedništva luteransko-katolička komisija smatra da je Zajednička izjava o opravdanju, unatoč svim njezinim ograničenjima ${ }^{35}$, ipak vrhunac razgovora, tj. prema nama osobno jedan vrlo dobar konsenzus ${ }^{36}$, dviju strana s obzirom na učenje o opravdanju te da ju je i danas potrebno slijediti.

Oba ova dokumenta jasan su pokazatelj kako je između katolika i luterana moguće postići visoku suglasnost oko važnih pitanja koja nas već stoljećima, nažalost, dijele. Naime, problematika opravdanja stoljećima je opterećivala luterane i katolike da bi se tek 1999. godine došlo do zaključka kako se ipak oko važnih stvari u ovom pitanju možemo složiti te da razlike oko ovog pitanja koje su preostale nisu dovoljan

${ }^{32}$ A. E. McGRATH, Il pensiero della Riforma. Una introduzione, Torino, ${ }^{2} 1995 ., 155$.

${ }^{33}$ D. SALA, Francesco e Lutero. La commemorazione comune dei 500 anni della Rirofma a Lund, in Svezia, u: Il regno - attualità e documenti 18(2016.), 518.-519.

${ }^{34}$ http://w2.vatican.va/content/francesco/it/homilies/2016/documents/papafrancesco_20161031 omelia-svezia-lund.html (2. III. 2017.)

${ }^{35}$ S obzirom na komentar Zajedničke izjave iz 1999. godine upućujemo na: ISTITUTO PER LA RICERCA ECUMENICA DI STRASBURGO, Commento alla dichiarazione comgiunta sulla dottrina della giustificazione, $\mathrm{u}$ : A. MAFFEIS (ur.), Dossier sulla giustificazione. La dichiarazione congiunta cattolico-luterana, commento e dibattito teologico, Queriniana, 2000., 93.-143. O teološkoj raspravi o Zajedničkoj izjavi upućujemo na treći dio knjige A. MAFFEIS (ur.), Dossier sulla giustificazione. La dichiarazione congiunta cattolico-luterana, commento e dibattito teologico, 147.-310.

${ }^{36}$ Jüngen G. Astfalk 1999. godine o konsenzusu koji je postignut u ovom dokumentu napisao je sljedeće: »Konsenzus ne znači puno slaganje. U konsenzusu se razlike ne skrivaju, nego jasno pokazuju. I upravo je ovo, po mom sudu, posebni doprinos Zajedničke izjave: ona prezentira različite poglede luterana i katolika u svim detaljima. [...] Različitosti su nabrojane, ali se više ne shvaćaju kao one koje dijele crkvu «. F. FERRARIO, P. RICCA (ur.), Il consenso cattolico-luterano sulla dottrina della giustificazione, Torino, 1999., 5 . 
razlog za podjelu među Crkvama. Da je ovakva suglasnost i spremnost za dijalog s obje strane oko pitanja o opravdanju postojala za života Martina Luthera, možemo sa sigurnošću ustvrditi kako bi podjele imale kudikamo manje razarajuću snagu te možda ne bi ni došlo do razdiranja zajedništva.

Drugi dokument govori nam, između ostaloga, o još jednom važnom pitanju koje je također stoljećima opterećivalo luteransko-katoličke odnose: lik i djelo Martina Luthera. Od otpadnika i heretika, Luthera se u katoličkim krugovima počelo doživljavati drukčije, tj. mnogo pozitivnije, a što je u dokumentu Od sukoba do zajedništva i jasno izraženo. Osim toga, o Lutheru su se pozitivno i u ekumenskom duhu uvažavanja izrazili i papa emeritus Benedikt XVI. koji ga je 2011. godine u Erfurtu, za vrijeme posjeta bivšeg augustinskog samostana, nazvao »svjedokom evanđelja $\ll^{37}$, te aktualni papa Franjo ${ }^{38}$ koji je vrlo pozitivno govorio o Lutheru ${ }^{39}$.

Oba nam ova dokumenta govore da u Katoličkoj Crkvi odavno pušu neki novi, tj. puno pozitivniji vjetrovi u smislu pozitivnog vrednovanja i uvažavanja drugih i drukčijih stavova. Međutim, ovo ne treba shvatiti u smislu da bi Katolička Crkva napuštala osnovne postavke, bilo svoje ekleziologije bilo svog ostalog važnog teološkog učenja. Prije se treba shvatiti u smislu da se dopušta mogućnost drukčijeg mišljenja i kao takvog ga se uvažava te se vlastito stajalište po potrebi može i nadopuniti. Naravno da se to u ekumenskom duhu očekuje i od druge strane u partnerskom dijalogu.

\section{Zaključak}

Kada pogledamo ekumenski razvoj u Katoličkoj Crkvi u 20. stoljeću, onda ga s pravom možemo podijeliti na dva dijela: prije i nakon Drugog vatikanskog sabora. Oba ova razdoblja imaju svoja bitna obilježja i nije ih potrebno skrivati, umanjivati ili pak falsificirati. Katolička Crkva u odnosu na ekumenizam postupno je sazrijevala te je trenutno $\mathrm{u}$ fazi u kojoj zasigurno svojim bilateralnim kontaktima predvodi i vuče naprijed ekumenski pokret $\mathrm{u}$ cjelini.

Istina je da mnogo toga nismo spomenuli u ovome radu. Ipak, smatramo da smo istaknuli najvažnije korake i naglaske te da su nam oni dovoljan primjer golemog

\footnotetext{
${ }^{37}$ COMMISSIONE LUTERANA-CATTOLICA SULL'UNITÀ E LA COMMEMORAZIONE COMUNE DELLA RIFORMA NEL 2017, Dal confitto alla comunione, Bologna, 2014., br. 30.

${ }^{38}$ Više o ekumenizmu pape Franje može se vidjeti u knjizi na hrvatskom jeziku: I. MACUT, Ekumenizam pape Franje, Zagreb, 2016. Vidi još i: M. BRÄUER, Pope Francis and Ecumenism, u: The Ecumenical Review 69(2017.), 4.-14.

${ }^{39}$ Usp. La leadership del papa. Intervista a Martin Junge, segretario della Federazione luterana mondiale, u: Il Regno - attualità 18(2016.), 521.
} 
ekumenskog napretka, posebice u Katoličkoj Crkvi, a koji onda može poslužiti kao primjer i drugim ekumenskim partnerima da se ne boje otvoriti i prihvatiti promjene u vlastitoj Crkvi i crkvenoj zajednici kako bi onda time mogli doprinositi i promjeni cjelokupnog kršćanstva, a čemu je Katolička Crkva očiti primjer.

500. obljetnica od početka Reformacije koju obilježavamo u ovoj 2017. godini jedan je od važnih koraka prema vidljivom jedinstvu. Ova nam je obljetnica, također, poticaj da se ne smijemo jednostavno zadovoljiti s onim što je do sada postignuto, a postignuto je zaista mnogo, nego je potrebno staviti naglasak na ono što je još pred nama. Mnogo je još teških pitanja otvoreno o kojima će se još trebati postići konsenzus. Ipak, imajući u vidu cjelokupni dijalog između luterana i katolika, onda nam taj napredak ulijeva optimizam i osnažuje nadu da smo na dobrom putu i da je vidljivo jedinstvo pred nama. Ono će biti, kako je to rekao papa Benedikt XVI., Božji dar, ali taj dar ne smijemo primiti nespremni, nego uložiti sve svoje napore i trud da ga dočekamo spremni kako bismo ga mogli kao takvog prihvatiti i u konkretnom životu zaživjeti. 


\title{
IMPORTANT STEPS ON THE PATH OF ECUMENISM IN THE CATHOLIC CHURCH WITH SHORT REFERENCE TO THE CATHOLIC-LUTHERAN DIALOGUE
}

\author{
Ivan MACUT*
}

Summary: In this article, we are discussing the main ecumenical steps that have been taken in the Catholic Church regarding ecumenism with special emphasis on the Catholic-Lutheran dialogue. Besides the introduction and conclusion, the article is divided into four short chapters. In the first chapter, entitled $\gg$ The Week of Prayer for Christian Unity $\ll$, we briefly presented the origin and emphasized the importance of this week of prayer. Namely, in many parish communities it is often the only ecumenical activity throughout the year. The second chapter speaks of the Second Vatican Council and the ecumenical opening of the Catholic Church through several different emphases: $\gg$ Focus on Ecumenism «, $\gg$ Secretariat for Christian Unity $\ll, ~ \gg$ The Presence of Non-Catholic Observers at the Council «, $\gg N e w$ Approach to Ecumenism - Unitatis Redintegratio «, $\gg$ Subsistit in «, »Hierarchia veritatum $\ll$. The third chapter discusses the joining of the Catholic Church in the $\gg$ Faith and Order « movement, while the fourth chapter discusses the $\gg$ Joint Declaration on Justification « from 1999 and the 2013 document entitled $\gg$ From Conflict to Communion «. In conclusion, we can say that the attitude of the Catholic Church in the 20th century towards ecumenism should be divided into two parts: before and after the Second Vatican Council. The 500th anniversary of the Reformation is an opportunity to continue the ecumenical dialogue between the Lutherans and the Catholics even more fervently, and to make the final steps towards a visible unity.

Keywords: Week of Prayer for Christian Unity, Second Vatican Council, Lutherans, Subsistit in, From Conflict to Communion.

\footnotetext{
* Postdoctoral fellow Ivan Macut, Ph. D., Catholic Faculty of Theology University of Split, Zrinskofrankopanska 19, 21000 Split, Croatia, ivanmacut@libero.it
} 